\title{
A Balance between Procedural Justice and Substantive Fairness: Improving the ICSID Arbitration Annulment System
}

\section{Huan Qi ${ }^{*} \&$ Yutian Guan ${ }^{* *}$}

As the most important dispute resolution mechanism in international investment, the ICSID system is valued for the efficiency of its proceedings and the finality of its awards. Due to the significance of ICSID to international investment laws, the international arbitration community has been calling for a high degree of substantive fairness in ICSID awards. However, based on past decisions, ICSID has not been able to strike a balance between procedural justice and substantive fairness. The drafters of the ICSID Convention intended the ICSID internal annulment system to be an error correction mechanism or a remedy for the parties to a ruling, when an arbitral tribunal or an arbitration report seriously violated the provisions. The ICSID annulment procedure is different from the appeal mechanism, and its review is based on extremely limited reasons and does not include a review of legal errors. Currently, the third working group of UNCITRAL is reforming the ISDS system, and the revision of the ICSID arbitration rules is also underway. This article discusses how to develop the current ICSID annulment system to promote greater substantive fairness in ICSID decisions.

* Professor at the Law Faculty of the China University of Political Science and Law ("CUPL"), Beijing, China. LL.B./LL.M./Ph.D. (CUPL), Diplôme d'Université, Droit en Europe (Paris 1). ORCID: https://orcid.org/0000-0002-7579-8964. The author may be contacted at: cupl_gipaper@ 163.com/Address: No.25 Xi Tu Cheng Road, Haidian District, Beijing 100088, P.R. China. This research was supported by CUPL innovative research program [中国政法大学创新科研项目资助 (项目号19ZFG82008)].

** Postgraduate student at International Law School of CUPL. All the websites cited in this article were last visited on August 8, 2019. 
Keywords: ICSID Convention, Arbitration Annulment System, Arbitration Remedy Mechanism, Manifest Excess of Power, Substantive Fairness

\section{INTRODUCTION}

According to the Convention on the Settlement of Investment Disputes between States and Nationals of Other States ("ICSID"), the remedies within ICSID comprise rectification, interpretation, ${ }^{2}$ revision, ${ }^{3}$ and annulment. ${ }^{4}$ Among them, annulment is considered the most severe and the last resort to protect the fairness of ICSID awards. Pursuant to paragraph (1) of Article 52 of the Convention, either party may request an annulment of an ICSID award on the following grounds: (i) the Arbitral Tribunal was not properly constituted under ICSID; (ii) the Tribunal has manifestly exceeded its powers; (iii) there was corruption on the part of a member of the Tribunal; (iv) there has been a serious departure from a fundamental rule of procedure; or (v) the award has failed to state the reasons on which it is based. In practice, the annulment system is barely satisfactory and less effective than expected.

\section{Perceived Drawbacks of the ICSID Annulment System}

\section{A. Conflict of Values: Substantive Fairness v. Procedural Efficiency}

Arbitration is more efficient than litigation for the finality of an award. As an important rectification mechanism for awards, annulment embodies the pursuit of fairness in an arbitration. This, however, does not mean that annulment is suitable under any circumstance. Normally, only when procedural justice cannot be achieved can an award be annulled; the ICSID annulment scheme is of no exception. The grounds for annulment provided in paragraphs (1)-(5) of ICSID Article 52 are essentially procedural defects.

ICSID ad hoc committees (hereinafter ad hoc Committee) have always tried to distinguish ICSID Article 52 from an appeal system in their decisions and prevented Article 52 from being used as a basis for substantive review of ICSID 
awards. ${ }^{5}$ The ad hoc Committees have frequently stressed that an ICSID award should only be reviewed on limited procedural grounds. Also, it is not appropriate for an ad hoc Committee to identify tiny procedural flaws to annul an award so as to negate significant mistakes in substantive issues. Nor shall an ad hoc Committee annul an award by misinterpreting the rules for annulment which are procedural in nature. ${ }^{6}$ Since $M I N E{ }^{7}$ the above approach to interpret ICSID annulment provisions has been strictly followed by subsequent ad hoc Committees, and in most cases, awards have only been nullified for procedural defects. Statistics show that 5 among 170 ICSID cases between 2011 and 2018 were nullified. ${ }^{8}$

Nevertheless, given the inherent requirements of neutrality and justice, arbitration should never pursue efficiency at the expense of substantive fairness. After all, only when the substantive issues are fairly decided, a dispute is truly resolved. Moreover, given that significant procedural mistakes may lead to unfairness in dealing with substantive issues, the application of procedural fairness is ultimately to promote substantive fairness. According to ICSID Article 53, a decision on annulment is final and binding. It means that neither party is entitled to seek remedies or challenge that decision through other means, which in turn indicates that nullification is the last resort to remedy an ICSID award. As a result, to ensure fairness, ad hoc Committees should be cautious when annulling awards.

However, procedural efficiency and substantive fairness by nature would conflict with each other as one can only be strengthened at the expense of another. Consequently, it has been long-debated how to draw a boundary between the two and to what extent substantive fairness should be protected. ${ }^{9}$ No consensus has been reached yet, however.

The authors believe that ICSID overly emphasizes finality of awards, which has limited itself to the protection of procedural fairness and consequently, the protection of substantive fairness has been overlooked.

\section{B. Current Situation of an Annulment System: Different Conclusions May Be Reached in Similar Cases}

ICSID Article 52 was derived from the Draft Convention on Arbitral Procedure drafted in 1953 by International Law Commission ("ILC"). ${ }^{10}$ The Draft Convention on Arbitral Procedure was elaborately designed to formulate a unified rule of international law on international arbitration procedure, which later became 
the 1958 Model Rule on Arbitral Procedure. ILC realized that finality of an award was the key feature of arbitration, but remedies should be available for awards of extreme unfairness. ${ }^{11}$ To find a balance between finality and fairness, ILC clarified that arbitration awards should not be appealed, but their validity could be only challenged under limited grounds, which gave rise to the annulment mechanism. ${ }^{12}$

Although it has been frequently argued that the purpose of ICSID annulment mechanism is merely to protect procedural justice of ICSID arbitration and therefore is different from an appeal system, ${ }^{13}$ ad hoc Committees differ on the relative importance of substantive fairness and procedural justice, resulting in difference in focus in the past decisions. Meanwhile, as paragraph (1) of ICSID Article 52 is ambiguous, ad hoc Committees have a large degree of discretion over its the application. Besides, there is no rule of stare decisis; so even if the same paragraph is quoted as the ground for annulment, the results may not be the same.

In practice, it is not uncommon that different decisions were reached in the same ICSID case. On the one hand, if the errors in the award could not be remedied by rectification, interpretation, revision or other means prescribed in Articles 49 to 51 of the Convention, and when the procedural defects were not serious enough to warrant an annulment, the ad hoc Committees have chosen to either affirm the award (thereby ensuring the finality of awards and making any remedial measures impossible), or examine the substantive issues to ensure substantive fairness (whereby an effect of appeal was de facto achieved). On the other, the ad hoc Committees overemphasizing procedural justice sometimes annulled awards which should not have been nullified due to technical defects, so that they induced the parties to enter a new arbitration or even a second annulment. This approach not only unreasonably extends the proceedings and sacrifices the efficiency pursued by ICSID, but also offers an undue opportunity to applicants who wish to put off the execution of the award. Apparently, neither procedural efficiency nor substantive justice can be achieved under either approach. ${ }^{14}$

Furthermore, divergent interpretations on the same clause lead to uncertainty. ${ }^{15}$ The lack of predictability directly undermines the stability of the ICSID annulment system and indirectly affects the authoritativeness and credibility of the entire ICSID system. The instability is, to a large extent, originated from the ambiguity of Article 52. 


\section{Disputes on the Application of ICSID Article 52.1(b)}

ICSID Article 52.1(b) stipulates: "Either party may request annulment of the award by an application in writing addressed to the Secretary-General if the Tribunal manifestly exceeds its power." This clause is the most commonly and frequently cited ground for annulment. ${ }^{16}$ In fact, the provision has been invoked as the basis for annulment in almost all annulment cases so far. The clause is also considered a necessary safeguard against the abuse of powers of arbitrators. ${ }^{17}$

In Soufraki, ${ }^{18}$ the ad hoc Committee considered that the boundaries of a Tribunal's powers are objective criteria set out in different ICSID provisions, namely, Article 25 relating to jurisdiction, Article 42 dealing with the applicable law, and the subjective limits set by the disputing parties' consents. ${ }^{19}$ Accordingly, a Tribunal "manifestly exceeding its power" is mainly reflected in the defects of either the exercise of jurisdiction or wrong application of the law. ${ }^{20}$ The Convention, however, does not provide any clarification on "manifestly exceeds its power" and the clause has been applied inconsistently.

\section{Interpretation OF "THE Arbitral Tribunal Manifestly EXCeeded its Power"}

\section{A. The Ad hoc Committee's interpretation of 'manifestly'}

Article 52.1 (b) of the Convention has two main elements, namely 'apparently' and "exceeded its power." According to the drafting history of ICSID, there have been scholastic debates on the situations where "an arbitral tribunal exceeds its power," but no connotation and denotation of 'manifest' are reached yet. ${ }^{21}$ According to Article 42 (2) of the Convention, "the Tribunal may not bring in finding of non liquet on the ground of silence or obscurity of the law." In other words, Tribunals should not refuse adjudication because of ambiguity of provisions. This gives the $a d$ hoc Committees ${ }^{22}$ relatively large discretionary space when invoking Article 52.1 (b). ${ }^{23}$

\section{Scope of application is unclear}

As mentioned above, Tribunals" "manifest excess of their powers" is primarily reflected in their jurisdiction or application of laws. Be it an ICSID annulment 
practice or scholars' opinion, it is widely agreed that Tribunals should consider whether the defect is 'manifest' when addressing defects in application of laws. However, when it comes to jurisdiction, scholars believe that it is not necessary to consider the 'manifest' element, since a Tribunal either has jurisdiction or not, and there is no intermediate state. ${ }^{24}$ For instance, Philippe Pinsolle commented: "One cannot be half-right or half-wrong when it comes to jurisdictional issues. Either there is jurisdiction of the Centre and competence of the arbitral tribunal, or there is not. If there is not, the award must be annulled. ${ }^{25}$ According to his opinions, if a Tribunal goes beyond its jurisdiction, it will not be able to make an effective decision, even if it has not "exceeded its powers manifestly."

Another view is that since 'manifestly' and "exceeded its power" are both criteria stipulated in Article 52.1 (b), the 'manifest' element shall also apply to jurisdictional issues. Only if the arbitral tribunal exceeds its power 'manifestly' will ICSID give up the finality of an award for substantive justice. ${ }^{26}$ In Soufraki, the ad hoc Committee maintains:

The ad hoc Committee sees no reason why the rule that an excess of power must be manifest in order to be annullable should be disregarded when the question under discussion is a jurisdictional one [...] the requirement that an excess of power must be "manifest" applies equally if the question is one of jurisdiction. [...] Only if an ICSID tribunal commits a manifest excess of power, whether on a matter related to jurisdiction or to the merits, is there a basis for annulment. ${ }^{27}$

MTD, Azurix and Enron's ad hoc Committees shared similar views in their decisions. ${ }^{28}$

\section{Different standards of applications}

i. 'Obvious' standard

Some believe that the level of effort required to detect a Tribunal exceeding its power cannot be too high, since otherwise it would encourage the ad hoc Committees to examine the substantive issues. Christoph Schreuer comments that "the Secretary-General will refuse registration only if the lack of jurisdiction is so obvious that the request does not deserve consideration by a tribunal. ${ }^{29}$ This indicates that Mr. Schreuer adopts the 'obvious' standard in interpreting 'manifest.'

The ad hoc Committee in Wena also adopted a similar view, saying that 
"the excess of power must be self-evident rather than the product of elaborate interpretations one way or the other. When the latter happens the excess of power is no longer manifest. ${ }^{, 30}$ Similarly, the ad hoc Committee in Repsol held that "when excess of the power can be found by reading the award, it can be regarded as obvious. ${ }^{31}$ The Klöckner I, ${ }^{32}$ Azurix, ${ }^{33} \mathrm{CDC}^{34}$ the ad hoc Committee also held a similar view.

ii. 'Tenable' standard

While some ad hoc Committees indicate that only if the actions taken by the Committee are exceeding its power so much that it is no longer tolerable, other Committees will consider whether the award is tenable when analyzing 'manifestness. $^{, 35}$

Klöckner I is the first case that adopted the 'tenable' standard. The ad hoc Committee acknowledged that the Tribunal's decision was rather vague ${ }^{36}$ and the explanation was not convincing. ${ }^{37}$ However, since the Tribunal's verdict "appeared to be tenable and not arbitrary, it did not violate Article 52.1 (b) and was not sufficient to constitute a revocation.",38 The ad hoc Committee in MTD held: "An award will not escape annulment if the tribunal while purporting to apply the relevant law actually applies another, quite different law. But in such a case the error must be 'manifest,' not arguable.",39

\section{iii. "Substantially manifest" standard}

The third standard was first proposed by the Vivendi ad hoc Committee. The Committee believed that to decide whether a Tribunal has exceeded its power, the consequences of the Tribunal's action should be taken into account, and "only where the failure to exercise a jurisdiction is clearly capable of making a difference to the result that it can be considered a manifest excess of power." In that case, since the Tribunal did not exercise the jurisdiction conferred on it by ICSID and the concerned bilateral investment treaty ("BIT"), the failure to act affected the final award, and therefore the Tribunal had exceeded its powers. The ad hoc Committee in Soufraki stated that, regardless of the interpretation of 'manifest,' "a manifest excess of power implies that the excess of power should at once be textually obvious and substantively serious." $"$ "1

We believe that in the past ICSID annulment decisions, the Tribunals have 
not been consistent in their interpretation of 'manifest.' In particular, all three possible approaches to interpret 'manifest' have their inherent weaknesses. The 'obvious' standard defines 'manifest' too narrowly. Given the complexity of cases, when Tribunals are exceeding their powers it is likely to seriously affect the fairness of their awards. Although the 'obvious' standard may help to maintain finality of awards, many controversial cases that should have triggered the annulment mechanism would be excluded, and as a result, fairness of ICSID awards and authority of the system would be undermined. The last two standards blur the boundaries between 'manifest' and "excess of power," thereby making the boundaries subject to the discretion of the ad hoc Committees and the interpretations arbitrary or confusing. Additionally, they open the door for a substantive review of Tribunals' awards by Committees, which deviates from the purpose of the ICSID remedy system.

\section{B. "Manifest Excess of Power" Reflected in "Defects in Jurisdiction"}

Article 25 of the Convention provides the conditions to establish the jurisdiction of a Tribunal, namely: (1) the dispute should be a legal dispute between a Contracting State/any constituent subdivision or agency of a Contracting State designated to the International Center for Settlement of Investment Disputes (hereinafter the Center) by that State, and a national of another Contracting State; (2) the dispute should be one arising directly out of an investment; and (3) the parties to the dispute consent in writing to submit the dispute to the Centre. If any of these elements is not satisfied when a Tribunal exercises its jurisdiction, the Tribunal exceeds its powers. Yet, due to the lack of clarity on the application of these clauses, the annulment decisions made by the ad hoc Committee are often inconsistent.

In Soufraki, the applicant argued that the Tribunal's examination of the nationality issue, which should be within the purview of a domestic administrative body, constituted "manifest excess of power." However, the ad hoc Committee was convinced that the Tribunal did not exceed its powers. It decided that the Tribunal had to verify the nationality of the applicant in order to ascertain the Tribunal's competence over the case. The Committee said that in establishing its jurisdiction, the Tribunal did not have to limit its resources to the identity certificate made by the domestic authority. ${ }^{42}$

In $C M S$, in response to Argentina's assertion that the Tribunal had gone beyond 
its jurisdiction in identifying the investor, the ad hoc Committee interpreted the US-Argentina BIT and said that CMS's capital investment in TGN constituted an investment under the relevant BIT, and thus CMS should be recognized as an investor. ${ }^{43}$ This decision, however, was widely criticized. ${ }^{44}$ The ad hoc Committee should have examined whether the Tribunal had exceeded its powers rather than whether the award made by the Tribunal was reasonable. It was clear that the scrutiny of the Committee had gone beyond the award to the substantive provisions of the BIT.

The ad hoc Committee in MHS believed that since 'investment' is not defined in the Convention, Tribunals should make a broad interpretation taking into account the Malaysia-UK BIT, rather than depending solely on the criteria established in the previous ICSID cases (such as the Salini criteria). ${ }^{45}$ Therefore, the Tribunal in fact had jurisdiction but it did not exercise it. In this regard, the Committee believed to constitute manifest excess of powers. The annulment decision was also criticized for re-examining the substance of the award.

\section{C. "Manifest Excess of Power" Reflected in "Application of Laws"}

\section{The boundary between "failure to apply the proper law" and "error of law"} is blurred

Considering the application of laws, the ICSID annulment system distinguishes "failure to apply the proper law" from "error of law." The former refers to a situation where a Tribunal has not applied the correct substantive law which should have been applied, while the latter describes a scenario where, although the Tribunal has referred to the correct governing law, there are flaws in the application of specific provisions. ${ }^{46}$ A majority of scholars agree that a Tribunal's failure to apply the proper law is a procedural error and it constitutes "manifest excess of power," whereas "error of law" mainly refers to a substantive error and should be thus excluded from the ambit of the ICSID annulment system. ${ }^{47}$ practice, however, the ad hoc Committees driven by different views have differed on what constitutes "failure to apply the proper law" and "errors of law."

For example, while the ad hoc Committee did not define the "failure to apply the proper law," it provided a substantial argument over the meaning of the latter. When discussing the umbrella clause-related issues, the ad hoc committee recognized that the umbrella clause issues were matters of treaty interpretation, 
and thus failed to fall into the scope of reasons for annulment. ${ }^{49}$ In the following discussion of emergency situation, the committee first argued that the award should be annulled since the tribunal manifestly exceeded its power by precluding Argentina from relying on Article XI of the BIT and on the principle of necessity under customary international law when deciding whether Argentina violated its obligation under the BIT. ${ }^{50}$ The rationale is that, had not Argentina been precluded from relying on the above, the ad hoc Committee might have found that Argentina was not liable for any breach of the BIT. ${ }^{51}$

However, the ad hoc committee itself was not entitled to find out that neither Argentina might rely on the principle of necessity under customary international law, nor did it have the right to decide on Argentina's violation of the BIT obligation. ${ }^{52}$ Conversely, the Sempra ad hoc Committee concluded that since the tribunal wrongfully equaled the principle of necessity under customary international law with that in BIT, the award should be annulled due to a failure to apply the proper law. ${ }^{53}$

On the other side, although the ad hoc Committee in Amco I fully acknowledged the distinction between the two concepts, it still recognized an "error of law" as a type of "manifest excess of power" and decided that since the Tribunal had not "applied the basic provisions of Indonesian law," it had exceeded its powers in calculating Amco's investment balance. ${ }^{54}$

We believe that the reason for the divergent views is that the ad hoc Committees and critics of the decision differ on what is the Tribunal's obligation in relation to "proper law." In the annulment proceedings, does the ad hoc Committee then have the right to decide what the proper law is? Or, is the power of ad hoc Committee limited to decide whether the proper law determined by the original arbitral tribunal is correctly applied?

Some considers that if the ad hoc Committee has the power to decide what the proper law is, it will inevitably take into account the substantive aspects of the laws, and as a result, the annulment decision will produce the same effect as an appeal, which is contrary to the purpose of Article $53 .{ }^{55}$ Others are of the view that identifying the proper law is within the inherent competence of the ad hoc Committee, and if the Committee does not have this power, Article 52.1 will be useless, so that the ad hoc Committee should have the right to make a decision on which is the proper law. This view is criticized, however. 


\section{When do "errors of law" constitute "manifest excess of power"?}

The ICSID's failure to strike a balance between substantive justice and procedural efficiency is well demonstrated to question when an "error of law" constitutes "manifest excess of power." Since no appeal system was intended under ICSID, "error of law" should not be considered a ground for annulment. ${ }^{57}$ Although this view is generally accepted, a significant number of awards have in fact been annulled on the basis of "error of law" in order to correct substantive unfairness.

In MINE, the arbitral tribunal should have applied the Guinean Uniform French Civil Code, but it made a mistake to apply the French Civil Code, although both provisions are identical. ${ }^{58}$ The ad hoc Committee considered that even if the wrong law had been applied, as long as the effects resulting from applying the wrong laws were the same as the effects from applying the right ones, the right laws should be deemed to have been applied, and therefore, the Tribunal had not exceeded its powers. ${ }^{59}$ Similarly, the ad hoc Committee of MCI believed that when there are a variety of feasible interpretations for a clause, as long as the Tribunal had adopted one of them, it had not exceeded its powers. ${ }^{60}$ Similarly, in $C D C$, the applicant claimed that the Tribunal did not apply the British precedents and legislations invoked by Seychelles, for which the Tribunal failed to apply the proper law. The ad hoc Committee considered that it is not the duty of the Committee to parse the meanings of English legal authorities. Rather, the ad hoc Committee was supposed to make a procedural review to determine whether or not the Tribunal honored the intent of the parties to have their dispute decided under English law. ${ }^{61}$

Nevertheless, the ad hoc Committees in both Soufraki and MCI also clarified that misinterpretation or misapplication of the proper law may, in particular cases, be so gross or egregious that no reasonable person could accept them and needs to be distinguished from a simple error. Manifest excess of powers is possible in those cases. ${ }^{62}$

The authors believe that the ICSID annulment system places great emphasis on procedural justice because its provisions are based on the rules of international commercial arbitration, and procedural justice is valued the most in commercial arbitrations. However, different from commercial arbitrations, ICSID is characterized by its high degree of autonomy, self-containedness and political independence. Since the ICSID annulment mechanism is the ultimate remedy for investment disputes, the ad hoc Committees must be very cautious when dealing 
with annulment applications. It has been suggested that since ICSID is a selfcontained mechanism not subject to supervision by any domestic court, the ICSID annulment system should put more emphasis on major substantive errors in the awards in order to safeguard the substantive fairness. ${ }^{63}$

\section{Models of External Reforms of ICSID Arbitration Mechanism}

Since the ICSID mechanism has stabilized after 50 years of implementation, it is more straightforward and easier to reform the system from outside than from inside. An external reform draws on effective measures established in other dispute resolution systems (which have been proved to effectively safeguard the fairness in dispute resolution) to set up a new system. Establishing a separate investment dispute resolution system including an appeal system is currently the most welcomed approach to reform ICSID.

\section{A. External Appeal System}

Currently, the treaty basis for ICSID decisions is primarily international investment agreements ("IIAs"), including investment chapters and clauses in BITs and free trade agreements ("FTAs"). As there is no permanent arbitral tribunal in ICSID and the ad hoc committees are constituted for individual cases, it is rather difficult to achieve a unified approach to interpret and apply more than 3000 IIAs and to ensure the substantive fairness of the decisions. Therefore, the introduction of an appeal system which allows an independent body to review the substance of ICSID decisions would help reduce the risks of injustice. Furthermore, it would increase the consistency of the decisions and make the laws more predictable. This model can be summed up as "an external appeal system" (hereinafter EAS model). It means establishing an arbitration system independent from ICSID including an appeal system and [is referred to as the dispute resolution forum] in the IIAs.

Major stakeholders have anticipated the establishment of an appeal system outside ICSID to rectify the drawbacks of ICSID remedy system. The US leaves leeway for a future appeal system of BIT disputes in its 2004 BIT template and its 2012 BIT template which retains the same arrangement. Similar arrangements 
can be found in other IIAs that the US concluded with other countries. The EU is also one of the strongest supporters of an EAS model. ${ }^{64}$ Statistics show that by the end of 2017, the overall number of arbitrations initiated by an investor from one EU member State against another totaled 168 (20 per cent of the total number of cases globally). ${ }^{65}$ Therefore, as a frequent participant in international investment disputes, the EU urges fairness in ICSID awards and has been opposed to the current ISDS model where international investment disputes involving states are resolved in the same manner as those between private investors. ${ }^{66}$

In recent, the EU has tried to promote an appeal system in the negotiation of new investment agreements, particularly the Comprehensive Economic and Trade Agreement ("CETA") and the EU Transatlantic Trade and Investment Partnership ("TTIP"). In the latest version of CETA published in February 2016, Article 8.28 (Chapter VIII) specifies the establishment of an appellate tribunal under the EU-Canada ISDS system. In terms of the means to achieve substantive justice in investment disputes, CETA goes further than ICSID. According to the said article, the authorities of the appellate tribunal are not limited to error-correction as stipulated at Articles 48, 49 and 52 of ICSID. If mistaking in both the application and interpretation of the proper law, ${ }^{67}$ such as obviously wrong determination of facts and relevant domestic laws, ${ }^{68}$ they can all be grounds for appeal. In this aspect, the appellate tribunal is clearly authorized to conduct substantive review on awards. In Article 10 of the investment chapter in the EU version of TTIP, the EU describes in detail the ideal constitutional, procedural and judicial rules of the appellate tribunal, including election of arbitrators, terms, required qualifications, procedures and voting. The EAS model has taken shape.

\section{B. The Problems Revolving around the Establishment of an Appellate System outside ICSID}

Although the EAS model might seem helpful at the first sight, in the long run, this approach is not as feasible as might be expected in terms of improving ICSID.

\section{Subversion of ICSID's autonomy}

Article 53.1 of ICSID expressly provides the exclusivity and autonomy of ICSID, thereby excluding any remedy outside ICSID. As a result, parties can either submit the dispute to a regional or bilateral ISDS system outside ICSID, 
or accept the governance of the ICSID without reservations. If the parties choose the former, there is no room to apply ICSID because ICSID is exclusive from any other system. Today, there is no multilateral treaty that regulates all investmentrelated issues and applies to all members in the international society. International investment laws can only apply mainly to contracting parties.

Because of complexity between key actors in international relations, a country might be subject to the jurisdiction of several appellate agencies established under different international investment regimes. If the EAS model becomes mainstream in the future, given different levels of protection available under different IIAs, the parties may be incentivized to engage in treaty-shopping in order to obtain a favorable decision. The ICSID system may be rendered useless, which is undoubtedly a huge blow to ICSID given its features of exclusivity and autonomy. In this sense, the EAS would not 'improve' ICSID and the EAS model has been widely criticized mainly for this reason. The US, a big trading country, is also skeptical about the EU's proposal. Although the US is the most frequently sued country in ISDS, it has not lost even one lawsuit. ${ }^{69}$ Expansion of the review system is bound to increase the risk of losing cases. According to Michael Forman, the US Trade Representative, the US is reluctant to give investors a second opportunity to seek relief. ${ }^{70}$

\section{Absence of applicable arbitration rules}

The substantive laws on which ICSID awards are based are IIAs. Although establishing an appellate tribunal under IIAs could avoid the complexities of creating a separate set of laws, most IIAs do not contain independent procedural rules. Even in CETA and TTIP, the procedural rules are not comprehensive. Fifty years after the establishment of ICSID, a complete set of arbitration rules comprising the Convention, the ICSID arbitration rules and the Additional Facility Rules have been formed under the ICSID framework. If proper procedural rules are absent, the procedural justice of awards is difficult to be achieved. Consequently, the substantive justice might be affected. In this sense, the model has the same disadvantages as ICSID.

\section{Fairness is hard to be guaranteed in arbitrator selection}

One of the key features of arbitration is 'neutrality,' which can be reflected in 
arbitrator selection. Currently, most arbitration rules stipulate that two of the arbitrators sitting in a given case are selected respectively by the parties in dispute, and the presiding one is designated by the arbitration body. In this regard, arbitrators are not permanent.

According to the EU version TTIP, the appellate tribunal is composed of six permanent arbitrators, two of whom shall be nationals of a Member State of the EU; two shall be nationals of the US; and two shall be nationals of the third countries. The EU and the US each nominates one of the two members from the third party countries together. ${ }^{71}$ However, in order to protect the fairness of arbitral tribunal, TTIP requires that the president and vice president of the appellate tribunal be nationals from the third countries. ${ }^{72}$ Although the composition of each division to hear an appeal case is random and unpredictable, ${ }^{73}$ given that more EU and US nationals will be seated in the appellate tribunal, the divisions to hear appeal cases are easily dominated by the EU and the US nationals. As a result, the outcomes of the arbitration are likely to lean towards the interests of the EU and the US. As the TTIP appellate system will be similar to the WTO appellate system and the WTO dispute settlement body is often considered to protect the interest of developed countries, it is unclear whether neutrality can be achieved under the TTIP construction.

\section{IMPROVEMENT WITHIN THE ICSID Arbitration System}

As the problems actually lie within the ICSID system, it may be more sensible to seek a solution within the system rather than from outside. Having in mind the original function and characteristics of ICSID, proponents of an internal reform came up with two solutions: one is to amend the present ICSID provisions on remedies, in particular, the annulment system, while the other is to build an appeal mechanism for investment disputes within ICSID.

\section{A. Building an Appeal Mechanism within ICSID}

1. This model is essentially the same as the EAS model

An ICSID appeal mechanism is basically the same with the external appeal 
mechanism mentioned above. The only difference is that the former forms part of the ICSID mechanism, and therefore the plan to build such a system requires a careful consideration of the entire ICSID regime. Since there is no material difference between the internal and external appeal system, the feasibility of an internal system is questionable. In fact, building such mechanism was first proposed after Klockner and Amco I. ${ }^{74}$ However, at that time, this proposal was widely regarded as "an unwelcome development," which would greatly expand the scope of the ad hoc Committee's review to errors of law. ${ }^{75}$

Even today, this proposal is still highly controversial. For investors' home countries, the profit gained by investors are the main economic benefits that the countries obtain from international investments. Therefore, only when the investors believe that an appeal mechanism may enhance their profitability will their home countries accept the new system. ${ }^{76}$ Nevertheless, the current ICSID mechanism is more in line with the investors' interests than a new appeal system is. Therefore, if no significant change occurs, the countries whose economies heavily rely on overseas investment will be more willing to maintain the status quo than to build a new appeal system. ${ }^{77}$

\section{The difficulty in amending the Convention}

Generally, it is difficult to revise a treaty if it concerns a number of countries. According to a 2013 ISDS report published by UNCTAD, at present, there are only sporadic revisions of IIAs, and parties to the IIAs only chose to revise articles closely related to their interests (so as to make these articles in line with their interests). ${ }^{78}$

As a multilateral convention with 161 member states, ${ }^{79}$ ICSID is facing the same difficulty. Pursuant to Article 66 of ICSID, ${ }^{80}$ the amendment of the Convention requires the decision approved by a majority of two-thirds of member States and the acceptance of all the member States. Moreover, although the wording of the relevant ICSID articles has been widely criticized for its ambiguity, such ambiguity may serve to balance the interests of various countries. If the Convention is revised to take away all the ambiguity, the efforts aiming to achieve a balance could become futile. From the perspective of sustainable development of ICSID, this proposal may not be practically feasible or widely supported.

On the other hand, since the ICSID arbitrations at present are inclined to 
protect interests of investors, it is the host countries that benefit the most from an appeal mechanism, particularly the developing countries. Therefore, the home countries of investors will try their best to prevent the establishment an appeal system, adding a big hurdle to building an appeal mechanism by treaty amendment under the current ICSID system.

Some are of the view that since it is impossible to revise the Convention directly, it would be better to revise the Convention among some of the member states in accordance with Article 41 of the Convention, following which an appeal mechanism can operate among these countries. ${ }^{81}$

Pursuant to Article 40 of Vienna Convention on the Laws of Treaties ("VCLT"), the revised treaty will only apply to members who have accepted the amendment, whereas the other members that have not done so are not bound by the revised version. Therefore, the revision will not affect those who have not accepted the amendment. ${ }^{83}$ In addition, the original Convention will still be applied between member states who have accepted the revised version and those who have not accepted the revision. ${ }^{84}$ Thus, the applicability of the appeal system is limited.

\section{B. 'Reparation' of the present ICSID Remedy System}

'Reparation' of the ICSID remedy system refers to the strictly internal improvement of ICSID in order to fix the internal defects of the ICSID remedy system through means other than increasing or decreasing the types of remedies available under ICSID. The proposal also aims to enhance arbitration transparency; improve independence of arbitrators; and unify treaty interpretations, which in turn will increase the certainty of legal rules, expediate issuance of awards and shorten the time to resolve disputes. These would finally improve the correctness of the awards, thereby achieving the goal of improving the fairness of arbitration.

The authors believe that only by reforming the annulment from inside the system, the inherent defects of ICSID can be fixed. Therefore, this proposal is more feasible and can be achieved through the following measures.

\section{Permitting ad hoc Committees to review substantive issues}

The ICSID annulment system could only review procedural matters because 'annulment' is generally accepted as a procedural supervision mechanism. However, the Convention itself does not stipulate that the substantive issues 
cannot be reviewed by an ad hoc Committee. As mentioned, the word 'manifest' used in Article 52.1(b) of ICSID leaves leeway for review of substantive issues. Consequently, the scope of review can be expanded to decisions that are manifestly wrong in substantive aspects.

Prior to 2006, the development of ICSID decisions could be roughly divided into three stages: the first stage is represented by Klockner I and Amco I, where the ad hoc Committees were under the criticism that the review of substantive issues wrongly blurs the boundary between an annulment and an appeal ${ }^{85}$; the second stage is represented by MINE, where the annulment system and the appeal system were again differentiated out of the same concern as in the first stage; and in the third stage, which is represented by Vivendi ${ }^{86}$ and Wena. ${ }^{87}$ Here, although the ad hoc Committees still emphasized the distinction between annulment and appeal, ${ }^{8}$ they conducted substantive review on the awards and decided that the Tribunals exceeded their power on the basis that they had already prejudiced the substantive outcome of the decision. ${ }^{89}$

In a word, the ICSID annulment mechanism has gone through primarily three stages as follows: (i) substantive review; (ii) procedural review; and (iii) substantive review. The ad hoc Committees' return to substantive review indicates that substantive analyses are reasonably necessary. From the perspective of the development of ICSID annulment system, it is inevitable that the ad hoc Committees shall be authorized to review the substantive issues of cases.

\section{2. 'Two-step' approaches for the evaluation of "manifest excess of power"} The first approach is that, in the annulment proceedings, the ad hoc Committees first make a decision on whether the Tribunal has exceeded its power; if the answer is 'yes,' it then turns to the question of whether the 'excess' is manifest or not. The other approach is that ad hoc Committees directly review whether the arbitral awards are manifestly unfair; if the answer is 'no,' it is unnecessary to decide whether there is excess of power. ${ }^{90}$ The difference between the two approaches can be summarized that the first one positively stipulates circumstances that allow annulment, while the second negatively stipulates the circumstances precluding application of annulment.

The authors believe that it is not necessary to decide which of the two approaches is better. In fact, both can supplement each other or even used together 
to decide whether an arbitral award contravenes Article 52.1 (b) of ICSID. In particular, if the party applying for annulment puts forwards arguments on procedural matters, the ad hoc Committee may adopt the first approach. In other words, it should determine whether there are procedural breaches in the first place, and if such breaches are not manifest at all, the special committee could decide that even though there is a procedural error, an annulment is rejected owing to the fact that the violation is not 'manifest.'

The approach avoids the risk of an award being annulled due to technical defects and helps to preserve finality of the ICSID decisions. If the party applies for annulment based on substantive errors, the ad hoc Committees could take the second approach and carry out a prima facie review of the substantive issues, in order to determine whether the substantive mistakes have resulted in a manifestly unfair outcome. If manifestly unfair outcomes do exist, the ad hoc Committees should annul the decision. If mistakes on substantive issues are not manifest, the ad hoc Committees shall decide that the Tribunals have not exceeded their powers. In this way, not only is efficiency ensured, but also substantive justice is protected.

\section{Conclusion}

In conclusion, the sustainable development of the ICSID arbitral mechanism requires substantives justice in its decisions. The present ICSID system is faced with such problems as absence of legitimacy, lack of uniformity of the awards, as well as the flaws on remedy mechanism. The source of the problems is that ICSID annulment mechanism excludes the substantive review of the awards.

Given that it is virtually impossible to establish an appeal mechanism or amend the Convention, we are of the view that authorizing the ad hoc Committees to review the substantive issues of cases in annulment stage and improving the procedural annulment rules simultaneously, not only enable ICSID to improve its current insufficient protection of substantive fairness, but also maintain the efficiency of proceedings and the finality of awards that ICSID always values by limiting the extent of substantial review of a case to the prima facie level. By noticing the significant role of ICSID in international investment, only by providing a high level protection to the substantial arbitration, ICSID can function 
well and actively in the international investment legal system.

\section{REFERENCES}

1. Convention on the Settlement of Investment Disputes between States and Nationals of other States ("ICSID Convention"), art. 49, available at https://icsid.worldbank.org/ICSID/ StaticFiles/basicdoc/partA.htm.

2. Id. art.50.

3. Id. art. 51.

4. Id. art. 52.

5. Klöckner Industrie-Anlagen $\mathrm{GmbH}$ and others v. United Republic of Cameroon and Société Camerounaise des Engrais ("Klöckner I") (Decision on Annulment I)[note the footnotes for others do not contain (Decision on Annulment)], ICSID Case No. ARB/81/2, qฯ 3, 61, 83 \& 120; Amco Asia Corporation and others v. Republic of Indonesia(“Amco I") (Decision on Annulment I), ICSID Case No. ARB/81/1, ๆๆ 23, 43; Maritime International Nominees Establishment v. Republic of Guinea ("MINE") (Decision on Annulment), ICSID Case No. ARB/84/4, ๆ 5.08; Wena Hotels Ltd. v. Arab Republic of Egypt ("Wena”) (Decision on Annulment I), ICSID Case No. ARB/98/4, $\uparrow 18$, etc.

6. Yanru Wei, Research on ICSID Arbitration Revocation System [ICSID仲裁撤销制度研 究] 159 (Xiamen University Press, 2007).

7. MINE, supra note 5.

8. ICSID, The ICSID Caseload-Statistics (2019-1), at 18, available at https://icsid.worldbank.org/ en/Documents/resources/ICSID\%20Web\%20Stats\%202019-1(English).pdf.

9. YanRu Wei, ICSID Zhongcai CheXiao Zhidu JiaZhi Dingwei Yanjiu [ICSID仲裁撤销制度价 值定位研究], 12 J. INT'L ECON. L. [国际经济法学刊] 366 (2005).

10. Documents of the Fifth Session Including the Report of the Commission to the General Assembly, [1953] 2 Y.B. Int'l L. Comm'n, U.N. Doc. A/CN.4/SER.A/1953/Add.1 (Article 30 of the Draft Convention on Arbitral Procedure), at 2.

11. C. Schreuer et al., Article 52: Annulment, in the ICSiD Convention: A Commentary 898-9 (2d ed. 2009).

12. Summary Records of the Fourth Session, [1952] 1 Y.B. Int'1 L. Comm'n, 153rd meeting, 9甲 64-84, and 154th meeting, qศ 1-18. Summary Records of the Fifth Session, [1953] 1 Y.B. Int'1 L. Comm'n, 191st meeting, U.N. Doc. A/CN.4/SER.A/1953, ๆๆ 77-105. See also History of THE ICSID CONVEnTIOn, Vol.II-1, 216-8 (ICSID Publication, republished in 2009).

13. WEI, supra note 6, at 168.

14. Id. at 29-30. 
15. Reform of Investor-State Dispute Settlement: In Search of a Roadmap ("UNCTAD Report”), at 3, available at http://unctad.org/en/PublicationsLibrary/webdiaepcb2013d4 en.pdf.

16. Updated Background Paper on Annulment for the Administrative Council of ICSID (May 5, 2016), at 53, available at https://icsid.worldbank.org/apps/ICSIDWEB/resources/ Documents/Background\%20Paper\%20on\%20Annulment\%20April\%202016\%20ENG. pdf.

17. R. Bishop \& S. Marchili, Annulment under the ICSID Convention 84 (2012).

18. Hussein Nuaman Soufraki v. United Arab Emirates ("Soufraki"), Decision of the ad hoc Committee on the Application for Annulment of Mr Soufraki, ICSID Case No. $\mathrm{ARB} / 02 / 7$, ๆ 37 (June 5, 2007).

19. BisHop \& MARCHILI, supra note 17 , at 81 .

20. WEI, supra note 13, at 89.

21. Id. at 88 .

22. Generally, the ad hoc shall belong to tribunal as well since it is the subject to give the annulment award.

23. WEI, supra note 13, at 98.

24. "Where jurisdiction is concerned the word 'manifest' should be limited to mean that the excess of powers is apparent from a strictly legal point of view on the examination of the text of the award." See D. Thompson, The Klöckner v Cameroon Appeal: A Note on Jurisdiction, 13:2 J. INT'L ARB. 99-100 (1986).

25. P. Pinsolle, Jurisdictional Review of ICSID Awards, 5 J. World Inv. \&Trade 616 (2004).

26. Bishop \& MARCHILI, supra note 17, at 92.

27. Soufraki, supra note 18, 9 甲 118-119.

28. Azurix Corp. v. Argentine Republic (“Azurix”), Decision on the Application for Annulment of the Argentine Republic, ICSID Case No. ARB/01/12, qศ 63-68 (Sept. 1, 2009); Enron Corporation and Ponderosa Assets, L.P. v. Argentine Republic ("Enron"), ICSID Case No. ARB/01/3, ๆ 69 (July 30, 2010); and MTD Equity Sdn. Bhd. and MTD Chile S.A. v. Republic of Chile ("MTD”), ICSID Case No. ARB/01/7, ๆ 47 (Mar. 21, 2007).

29. D.Caron, Reputation and Reality in the ICSID Annulment Process: Understanding the Distinction between Annulment and Appeal, 7:1 ICSID Rev.-Foreign Inv. L. J. 38 (1992); C. Schreuer et al., Article 52 - Annulment, in the ICSid Convention: A Commentary 939 (2009).

30. Wena, supra note 5, 925.

31. Repsol YPF Ecuador S.A. v. Empresa Estatal Petróleos del Ecuador (Petroecuador), ICSID Case No. ARB/01/10, Decision on Annulment, 36 (Jan. 8, 2007).

32. Klöckner I, supra note 5, $₫ 52$.

33. Azurix, supra note 28, 1 ๆ 68-69. 
34. CDC Group plc v. Republic of Seychelles (“CDC”), ICSID Case No. ARB/02/14, Decision on annulment, $\uparrow 41$.

35. Bishop \& MARCHILI, supra note 17 , at 86-7.

36. Klöckner I, supra note 5, ๆ 8.

37. Id. ๆศ 27-28.

38. Id. $₫ 52$.

39. MTD, supra note $28, \llbracket 47$.

40. Compañiá de Aguas del Aconquija S.A. and Vivendi Universal S.A. v. Argentine Republic ("Vivendi I"), ICSID Case No. ARB/97/3, Decision on Annulment, ๆ 86 (July 3, 2002).

41. Soufraki, supra note $18, \llbracket 40$.

42. Id. $ๆ 76$.

43. CMS Gas Transmission Company v. Argentine Republic, ICSID Case No. ARB/01/8, Decision on Annulment, 975 (Sept.25, 2007).

44. See, e.g., Bishop \& Marchili, supra note 17, at 85; C. Schreuer, Failure to Apply the Governing Law in International Investment Arbitration, 7 Austrian Rev. InT'L \& Euro. L. 194-5 (2002).

45. Malaysian Historical Salvors, SDN, BHD v. The Government of Malaysia, ICSID Case No. ARB/05/10, Decision on Annulment, ๆ 28 (Apr. 16, 2009).

46. WEI, supra note 6, at 96.

47. Id. See also Bishop \& MARCHILI, supra note 17, at 93.

48. For example, The committee of Klöckner I found that an 'error in judicando' could not be admitted as a cause for annulment "under penalty of indirectly reintroducing the appeal against the arbitral award," while, in MTD, Arthur Watts argued for the expansion of the committee's scope of review by expressing the opinion that a failure to apply the proper law should extend to cases in which the tribunal makes "a real and substantial mess of the law it was purporting to apply."

49. Enron Creditors Recovery Corp. (formerly Enron Corporation)and Ponderosa Assets, L.P. v. Argentine Republic, ICSID Case No. ARB/01/3, Decision on Annulment, 9345 (July 30, 2010).

50. Id. ๆๆ 406-407.

51. $I d$, ๆ 407.

52. Id, ๆ 408.

53. Sempra Energy International v. Argentine Republic, ICSID Case No. ARB/02/16, Decision on Annulment, ๆף 218-219 (June29, 2010).

54. Amco I, supra note 5, $995 \& 98$.

55. Bishop \& MARCHILI, supra note 17, \6.184.

56. A. Broches, Observations on the Finality of ICSID Awards, 6:2 ICSID Rev.-ForeIGN Inv. L. J. 365 (1991). 
57. History of the ICSID Convention: Documents Concerning the Origin and the Formulation of the Convention on the Settlement of Investment Disputes between States and Nationals of Other States, Vol. II-1, 518 (2009).

58. MINE, supra note 5, ๆ 6.38 .

59. Id. ๆๆ 6.38-6.43.

60. M.C.I. Power Group L.C. and New Turbine, Inc. v. Republic of Ecuador (“MCI Power”), ICSID Case No. ARB/03/6, Decision on Annulment, ๆ 51(Oct. 19, 2009).

61. CDC, supra note $34, \llbracket 47$.

62. Soufraki, supra note 18, ๆ 86; MCI Power, supra note 60, ๆๆ 42-44 \& 51.

63. See Sacerdoti and Lattanzi's opinion, recited from Broches, supra note 56.

64. 2012 US Model Bilateral Investment Treaty, art. 11.7(c); Chile-USFTA art. 10.19(10); CAFTA (Dominican Republic-Central America FTA), annex 10-F.

65. UNCTAD, Investor-State Dispute Settlement: Review of Developments in 2017, IIA Issues Note, June 2018, at 2, available at https:/unctad.org/en/PublicationsLibrary/ diaepcbinf2018d2_en.pdf.

66. United Nations Commission on International Trade Law Rules on Transparency in Treaty-based Investor-State Arbitration and Arbitration Rules (as revised in 2010, with Article 1, paragraph 4, as adopted in 2013), G.A. Dec. 68/109, U.N. Doc. A/RES/68/109 (Dec. 18, 2013).

67. Comprehensive Economic and Trade Agreement (“CETA") art. 8.28.2(a).

68. Id. art. 8.28.2(b).

69. For details, see Stockholm Chamber of Commerce, The U.S is skeptical of the European Commission's ISDS proposal, ISDS Blog, available at http://isdsblog.com/2015/11/13/ the-u-s-is-sceptical-of-the-european-commissions-isds-proposal/\#sthash.ZHLX9Wyc. dpuf.

70. "It's not obvious to me why you would want to give companies a second bite of the apple." See K. Hughes \& P. Blenkinsop, U.S. wary of EU proposal for investment court in trade pact, REUTERS, Oct. 30, 2015, available at https://www.reuters.com/article/ us-trade-ttip/u-s-wary-of-eu-proposal-for-investment-court-in-trade-pact-idUSKCN 0SN2LH20151029.

71. Transatlantic Trade and Investment Partnership (“TTIP”), EU textual proposal, available at http://trade.ec.europa.eu/doclib/press/index.cfm?id=1230. See also Chapter Service and Investment, art.10.2.

72. Id. art.10.6.

73. Id. art.10.9.

74. T. Walsh, Substantive Review of ICSID Awards: Is the Desire for Accuracy Sufficient to Compromise Finality, 24 Berkeley J. InT'L L. 452 (2006).

75. Id. See also M. Lynedjian, Reform of the WTO Appeal Process, 6 J. World Inv. \& Trade 816-7 (2005). 
76. Id.

77. See The outcomes of the cases concluded under ICSID, available at http://www.world bank.org/icsid/cases/conclude.htm.

78. UNCTAD Report, supra note 15 , at 6.

79. See Database of ICSID Member States, available at https://icsid.worldbank.org/apps/ ICSIDWEB/about/Pages/Database-of-Member-States.aspx.

80. ICSID Convention art. 66. It states: "If the Administrative Council shall so decide by a majority of two-thirds of its members, the proposed amendment shall be circulated to all Contracting States for ratification, acceptance or approval. Each amendment shall enter into force 30 days after dispatch by the depository of the Convention of a notification to Contracting States that all Contracting States have ratified, accepted or approved the amendment."

81. WEI, supra note 13, at 216.

82. VCLT art. 40(4).

83. UNCTAD Report, supra note 15 , at 6.

84. TTIP, supra note 71 , art. 40.4 .

85. C. Schreuer \& H. Christopher, Three Generations of ICSID Annulment, in Annulment OF ICSID Awards (IAI Series on International Arbitration No. 1) 17-8 (E. Gaillard \& Y. Banifatemi eds., 2004).

86. Vivendi I, supra note 40.

87. Wena, supra note 5.

88. Schreuer \& Christopher, supra note 85 , at 18-20.

89. Supra note 8 , at 102.

90. BISHOP \& MARCHILI, supra note $6, \llbracket 6.43$. 